\title{
SEROPREVALENCE STUDY ON THE CURRENT SITUATION OF BRUCELLOSIS IN HORSES AND DONKEYS IN ASSIUT GOVERNORATE
}

\author{
S.M. EL BERBAWY \\ Animal Health Research Institute (AHRI), Assiut Lab.
}

\section{ABSTRACT}

Received at: $12 / 6 / 2012$

Accepted: $18 / 7 / 2012$
Seroprevalence study was carried out on 423 donkeys and 48 horses of different ages and both sex for detection of the incidence of brucella. Seroreactive cases among donkeys at different locations in Assiut Governorate were 2.13\%, 1.65\% and $1.42 \%$ by using BAPAT, RBPT and TAT respectively, while by using Rivanol test (which detected the true positive only) it was $0.24 \%$. Quantitatively, 6 serum samples were seroreactive using TAT; $5(1.18 \%)$ of them revealed titer $1 / 10$ and last one $(0.24 \%)$ had a titer $1 / 40$ and also gave a titer $1 / 50$ by using Rivanol test with a percent $0.24 \%$ (the only true positive case allover the study). Two cases only showed clinical sings with a titer $1 / 10$, the first had a history of abortion at the 7 month of pregnancy and the other had a sore back lesion. The incidence of infection among young donkeys (less than 5 years old) was less that of old ones (more than 5 years old) and in females it was higher than in males. There are no any seroreactive cases among the 48 examined horses using the above tests. It can be concluded that the disease was not widely prevalent among horses and donkeys reared in Assiut Governorate, however even this low percent among donkeys can threat human and others animals. BAPAT was the most sensitive tests for the serological detection of brucellosis among donkeys, and horses but TAT\& Rivanol tests were the most accurate.

Key word: Brucellosis, Donkeys, Horses, Seroprevalence.

Abbreviation: $($ TAT $)=$ Tube Agglutination Test- $($ RBPT $)=$ Rose Bengal plate Test. $($ BAPAT $)=$ Buffered Acidified plate Antigen Test.

\section{INTRODUCTION}

Historically, equine brucellosis was recognized early when $B$. abortus was isolated from an aborted fetus of a mare (McNutt and Murray, 1924), where the disease is important not only as a clinical existence but also as a potential source of infection for man and other animals (Tel et al., 2011). Equines can contract infection through either contact with infected cattle or other species, ingestion of contaminated food or water and via penetration of skin or mucous membrane (Megid et al., 2010).

Equines showed a wide range of brucellosis occurrence, from $0.24 \%$ up to $37.5 \%$ (Gul and Khan, 2007). Worldwide brucellosis among donkeys were 5.5\% (Dragonas et al., 1967), 3.61\% (Yadav et al., 1991), 3.6\% (Musa, 2004), 7.4\% (Abo-Shehada, 2009), 2.12\% (Abdalla et al., 2010) and $0.25 \%$ (Tel et al., 2011), in Greece, India, Sudan-Darfur, Jordan, Eastern Sudan and Southeast Turkey, respectively. While through Egyptian previously research works, it was recorded as 46\% (Fahmy \& Salem 1974), 27.05\% (El-Bohy, 1979), 20.61\% (Abdel-Kader et al., 1995), 19.42 in male donkeys, and $21.15 \%$ in she- donkeys (Hamoda \& Montaser, 1998) in Assiut, Elsharkia, Assiut and Elkaliobia Egyptian Governorates, respectively.

Brucellosis among horses was widely investigated abroad and recorded as $0.8 \%$ (Dragonas et al., 1967),
16.28\% (Ali et al., 1985), 42.40\% (Izgur et al., 1988), $4.40 \%$ in male horses, $12.29 \%$ in mares (Yadav et al., 1991), 5.78\% (Ahmed \& Munir, 1995), no positive reactors (Omer et al., 2000), 60.59 (Solmaz et al., 2004), 0.24\% (Acosta- González et al., 2006), 9.5\% (Göz et al., 2007), 2.5 (Namavari et al., 2008), 20.7\% (Wadood et al., 2009), 2.5\% (Tahamtan et al., 2010), 14.7\% (Ehizibolo et al., 2011) and 13.68\% (Tel et al., 2011) in India, Netherlands, Greece, Iraq, TurkeyAnkara, India, Lahore-Pakistan, Eriteria, Van province of Turkey, Mexico, Hakkari- Turkey, Mashhad-Iran, Faisalabad- Pakistan, Northeast of Iran, North Nigeria, and Southeast Turkey respectively.

Few Egyptian studies recorded it as: $37 \%$ in Assiut (Fahmy \& Salem 1974), no positive reactors (Nashed, 1977) and 5.88\% (Abdel-Kader et al., 1995) and $8 \%$ in Elsharkia (Esmat, 1996).

Clinically equine brucellosis is generally asymptomatic since many serological surveys have indicated that horses may be exposed to brucella infection without developing clinical signs of the disease (Cyetnic et al., 2005; Acosta-González et al., 2006; Göz et al., 2007; Namavari et al., 2008 and Ehizibolo et al., 2011). However some clinical signs were reported in horses due to $B$. abortus infection as fluctuating temperature, arthritis, intermittent lameness, lethargy, painful swellings were found in 
different sites of the body mainly on supraspinous bursa (Fistulous withers) and atlantal bursa (Poll evil) (Carrigan et al., 1987; Esmat 1996 and Ocholi et al., 2004), or reproductive impairments as infertility in stallion and abortion in mare (Garg and Manchanda 1986).

Studies in relation to brucellosis in Egypt have focused mainly on domesticated ruminants (cattle, sheep and goats) neglecting the other contact farm animals which may threaten the spread of infection, so this work aimed to determine the prevalence of brucellosis among horses and donkeys in Assiut Governorate using 4 different serological tests (RBPT, BAPAT, TAT and Rivanol test) and in turn to evaluate the efficiency of these tests.

\section{MATERIALS and METHODS}

\section{I- Animals:}

A- Donkeys: 423 (150 $\widehat{\delta} \& 273$ o ) animals were involved in the serosurvey for detection of brucella Infection, 303 old animals (over 5 years old) while the rest 120 were young (less than 5 years). 350 of them were apparently healthy and the rest 73 were suffering from injuries, lameness or bursitis at different parts of the body. They were gathered from four different management sources as fallows:-

1-) 285 personal domestic animal holding (PDAH) (rural domestic animal holding) were collected from different localities belonging to Assuit Governorate.

No of Samples gave + Ve with both tests + No of samples gave - Ve with both tests

Agreement Percent between $=$ two serological tests
2-) 36 animals from village markets.

3-) 85 animals working in private farms.

4-) 17 animals working in governmental farms

B- Horses: Forty eight animals (12 $\delta \& 36$ o ), where 41 of them were old (over 5 years old) and the rest 7 animals were young (less than 5 years) and 39 of them apparently healthy, while the rest 9 were suffering from injuries, lameness and bursitis at different parts of the body. Managementally, 35 were PDAH, while the rest 12 were belonging to farms (11 to private and one to governmental farms).

\section{II- Antigens}

1- Buffered Acidified Plate Antigen $0.5 \%$ phenol was obtained from SAS-Scientific San Antonios, Texas, USA, and was carried out as described by Angus and Barton (1984).

2- Rose Bengal Antigen was supplied from Merieux Institute - France and was performed as described by Alton et al. (1988).

3- Standard B.abortus Agglutination Antigen for TAT was obtained from Veterinary Sera and Vaccine Research Institute, Abbasia, Egypt. The test was performed according to that described by Alton et al. (1988).

4- Rivanol Antigens were supplied by Veterinary Sera and Vaccine Research Institute, Abbasia, Egypt and the test was carried out according to Alton et al. (1988).

III- Test agreement \% with Rivanol results was calculated according to Sayour (1995) as follows:-
Total examined cases

\section{RESULTS}

The obtained results were recorded in Tables (1-3).

Table 1: Seroreactive animals using BAPAT, RBPT, TAT and Rivanol serological tests.

\begin{tabular}{|c|c|c|c|c|c|c|c|c|c|c|}
\hline \multirow{3}{*}{ Species } & \multirow{3}{*}{ Locality } & \multirow{3}{*}{$\begin{array}{l}\text { No.of } \\
\text { Animals }\end{array}$} & \multicolumn{8}{|c|}{ Seroreactors } \\
\hline & & & \multicolumn{2}{|c|}{ BAPAT } & \multicolumn{2}{|c|}{ RBPT } & \multicolumn{2}{|c|}{ TAT } & \multicolumn{2}{|c|}{ Rivanol test } \\
\hline & & & No & $\%$ & No & $\%$ & No & $\%$ & No & $\%$ \\
\hline \multirow{4}{*}{ Donkeys } & PDAH* & 285 & 6 & 2.1 & 5 & 1.75 & 4 & 1.40 & 1 & 0.35 \\
\hline & $\begin{array}{l}\text { Village } \\
\text { markets }\end{array}$ & 36 & 2 & 5.56 & 1 & 2.78 & 1 & 2.78 & - & - \\
\hline & Private farms & 85 & 1 & 1.18 & 1 & 1.18 & 1 & 1.18 & - & - \\
\hline & $\begin{array}{l}\text { Government } \\
\text { farms }\end{array}$ & 17 & - & - & - & - & - & - & - & - \\
\hline & Total & 423 & 9 & 2.13 & 7 & 1.66 & 6 & 1.42 & 1 & 0.24 \\
\hline \multicolumn{3}{|c|}{ Agreement \% with Rivanol test } & \multicolumn{2}{|c|}{98.1} & \multicolumn{2}{|c|}{98.6} & \multicolumn{2}{|c|}{98.8} & & \\
\hline \multirow{4}{*}{ Horses } & PDAH* & 35 & - & - & - & - & - & - & - & - \\
\hline & $\begin{array}{c}\text { Private } \\
\text { farms }\end{array}$ & 12 & - & - & - & - & - & - & - & - \\
\hline & $\begin{array}{l}\text { Government } \\
\text { farms }\end{array}$ & 1 & - & - & - & - & - & - & - & - \\
\hline & otal & 48 & - & - & - & - & - & - & - & - \\
\hline
\end{tabular}

*PDAH $=$ Personal Domestic Animal Holding. 
Table 2: Different titres of seroreactive donkeys for TAT and Rivanol Tests.

\begin{tabular}{|c|c|c|c|c|c|c|c|c|c|c|c|c|}
\hline \multirow{3}{*}{ Locality } & \multirow{3}{*}{$\begin{array}{c}\text { No of } \\
\text { donkeys }\end{array}$} & \multicolumn{6}{|c|}{ Tube agglutination test } & \multicolumn{5}{|c|}{ Rivanol test } \\
\hline & & \multirow[t]{2}{*}{$1 / 10$} & \multirow[t]{2}{*}{$1 / 20$} & \multirow[t]{2}{*}{$1 / 40$} & \multirow[t]{2}{*}{$1 / 80$} & \multicolumn{2}{|c|}{ Total reactors } & \multirow[t]{2}{*}{$1 / 25$} & \multirow[t]{2}{*}{$1 / 50$} & \multirow[t]{2}{*}{$1 / 100$} & \multicolumn{2}{|c|}{$\begin{array}{c}\text { Total } \\
\text { reactors }\end{array}$} \\
\hline & & & & & & No & $\%$ & & & & No & $\%$ \\
\hline PDAH & 285 & 3 & - & 1 & - & 4 & 1.40 & - & 1 & - & 1 & 0.35 \\
\hline Village markets & 36 & 1 & - & - & - & 1 & 2.78 & - & - & - & - & - \\
\hline Private farms & 85 & 1 & - & - & - & 1 & 1.18 & - & - & - & - & - \\
\hline Government farms & 17 & - & - & - & - & - & - & - & - & - & - & - \\
\hline Total & 423 & $\begin{array}{c}5 \\
(1.18 \%)\end{array}$ & - & $\begin{array}{c}1 \\
(0.24 \%)\end{array}$ & - & 6 & 1.42 & - & 1 & - & 1 & 0.24 \\
\hline
\end{tabular}

Table 3: Seroprevalence of brucellosis in donkeys in relation to sex and age.

\begin{tabular}{|c|c|c|c|c|c|c|c|c|c|c|}
\hline \multirow{3}{*}{\multicolumn{2}{|c|}{ Parameter }} & \multirow{3}{*}{ Total no } & \multicolumn{8}{|c|}{ Positive seroreactors } \\
\hline & & & \multicolumn{2}{|c|}{ BAPAT } & \multicolumn{2}{|c|}{ RBPT } & \multicolumn{2}{|c|}{ TAT } & \multicolumn{2}{|c|}{ Rivanol test } \\
\hline & & & NO & $\%$ & NO & $\%$ & $\mathrm{NO}$ & $\%$ & NO & $\%$ \\
\hline \multirow{2}{*}{ Sex } & $\begin{array}{c}\text { Male } \\
\text { donkeys }\end{array}$ & 150 & 1 & 0.67 & 1 & 0.67 & $1 *$ & 0.67 & - & - \\
\hline & $\begin{array}{c}\text { She } \\
\text { donkeys }\end{array}$ & 273 & 8 & 2.93 & 6 & 2.20 & 5 & 1.83 & 1 & 0.37 \\
\hline \multirow{2}{*}{ Age } & $<5$ years & 120 & 1 & 0.83 & 1 & 0.83 & $1 *$ & 0.83 & - & - \\
\hline & $>5$ years & 303 & 8 & 2.64 & 6 & 1.98 & 5 & 1.65 & 1 & 0.33 \\
\hline
\end{tabular}

$*$ a male donkey $<5$ years had a titer of $1 / 10$

\section{DISCUSSION}

Donkeys have a multipurpose use (especially in developing countries) for agricultural practices as transport and cart dragging where they are grazed, watered and kept in close contact with cattle and other farm animal species. Thus, donkeys may be exposed to contract (Ehizibolo et al., 2011) or transmit brucella infection since, they are possibly shedders of brucella organisms (Ocholi et al., 2004).

In the present work, brucella seroprevalence among donkeys in Assiut Governorate using BAPAT, RBPT, TAT and Rivanol tests on 423 donkey blood sera revealed that $9(2.13 \%), 7(1.66 \%), 6(1.42 \%)$ and $1(0.24 \%)$ were seroreactors respectively (Table 1). Nearly similar results among donkeys were obtained in Sudan (Musa, 2004; Abdalla et al., 2010), India (Yadav et al., 1991) and Turkey (Tel et al., 2011), while higher incidences were recorded in Greece (Dragonas et al., 1967), Jordan (AboShehada, 2009) and through all available Egyptian studies (Fahmy \& Salem 1974; El- Bohy 1979; Hamoda \& Montaser 1998 and Abdel- Kader et al., 1995). The higher incidence of brucella seroprevalence might be due to variation of samples collection, practical management and diagnostic techniques.
From Table (1), the seroreactive prevalences inbetween categories among donkeys showed that the higher BAPAT ratio was in village markets $(5.56 \%)$ then those of PDAH $(2.1 \%)$ and finally private farms $(1.18 \%)$ which indicate the high risk of disease transmission through animal movement in-between different locations.

Since Rivanol test acts with the true positive samples only as it detects IgG precipitating other immunoglobulins (Sayour 1995), it was the reference test in the present study. The only seropositive case allover this study (Rivanol positive) necessitated to study the agreement $\%$ of other serological tests with Rivanol which revealed that BAPAT, RBPT, TAT agree with Rivanol test by $98.1 \%, 98.6 \%$ and $98.8 \%$ respectively. TAT was the most serological test agreed with Rivanol test and it was the recommended test by many authors (EL- Bohy 1979; Abdel-Kader et al., 1995) in diagnosis of equine brucellosis as the superior test.

In the present study quantitatively, among the 6 seroreactors through TAT, their only 2 she- donkeys had clinical sings (showing titre $1 / 10$ using TAT) from the 9 seroreactive donkeys (using the most sensitive BAPAT). The first one had a previous history of abortion at the 7 month of pregnancy where 
the second one had sore back lesions. The rest of seroreactive donkey show no clinical signs even that case which had a titer of $1 / 40$ with TAT and a titre of 1/50 with Rivanol test (Table2). As the latent or dormant infection is the most probable form of brucellosis in equine (Acosta-González et al., 2006; Göz et al., 2007; Namavari et al., 2008 and Ehizibolo et al., 2011) even on experimental infection with $B$. abortus of a group of horses did not result in any clinical signs, but serological response of the organism was both marked and prolonged (MacMillan et al., 1982; MacMillan \& Cockrem 1986).

In the present study, Table (3) show the seroprevalence of brucellosis was found to be much less in male donkeys than that in she-donkeys which are in accordance to Hamoda \& Montaser (1998) as the females experience comparatively greater physiological stress during pregnancy and lactation due to which they are more susceptible to infection.

Moreover aged donkeys showed higher incidence than younger ones since the increase of antibodies positive reactions in older donkeys could possibly due to increase chance for exposure to infection (Ahmed \& Munir, 1995; Agab, 1997 and Kazi et al., 2005). Low prevalence in young may be explained on the basis that the animal may harbor the organism without expressing any detectable antibodies until their first parturition or abortion Wadood et al. (2009).

At Assiut, as owning horses as a kind of priding, the animals were kept in separate special pens away from other domestic giving no chance of infection transmission so no positive results were obtained either through the present study and Nashed (1977) while Abdel - Kadder et al. (1995) detected 5.88\%.

\section{CONCLUSION}

The results indicated that brucellosis is not widely distributed among horses and donkeys raised in Assiut province. However low percent donkeys reacted serologically to brucella infection without clinical evidence should not be neglected. The present findings proved that BAPAT was the most sensitive tests for the serological detection of brucellosis among donkeys, and horses but TAT was the most accurate serological test that agreed with Rivanol test.

\section{REFERENCES}

Abdalla, M.A.E.; Abdalla, S.H. and Elzaki, R. (2010): Prevalence of brucella abortus Gaderef State of Eastern Sudan. Tropentage, September 14- 16, Zurich "Word Food System - A contribution from Eurpe".

Acosta-González, R.I.; González-Reyes, I. and Flores-Gutièrrez, G.H. (2006): Prevalence of brucella abortus antibodies in equines of a tropical region of Mexico. Can. J. Vet. Res., 70 (4): $302-304$.

Abdel- Kader, H.A.; Abdel- Hafeez, M.M. and Bastawrows, A.F. (1995): Seroprevalence of brucellosis in Equines in Assiut Governorate. Assiut Vet. Med. J., 33(66): 84- 90.

Abo-Shehada, M.N. (2009): Seroprevalence of brucella species in equids in Jordan.Vet. Rec., 165: 267- 268.

Agab, H. (1997): Clinical signs of animal brucellosis in Eastern Sudan Rev. Elev. Med. Vet .Trop., 50(2): 97-98.

Ahmed, R. and Munir, M.A. (1995): Sero-prevalence of brucellosis in Horses, Dogs, Cats and Poultry. Pakistan Vet. J. 15 (2): $85-88$.

Ali, A.H.; Zaidan, W.A. and Sharma, V.K. (1985): Seroprevalence of brucellosis in horses in Iraq. Indian Vet. J., 62: 917-921.

Alton, G.G.; Jones, L.M.; Angus, R.D. and Verger, J.M. (1988): Techniques for brucellosis: laboratory. Paris: Institut National de la Recherche Agronomique, pp 63-129.

Angus, R.D. and Barton, C.E. (1984): The production and evaluation of a buffered plate antigen for use in a Presumptive test for brucellosis (cattle and swine). Develop. boil. Standard, 56: 349351.

Carrigan, M.J.; Cockram, F.A. and Nash, G.V. (1987): Brucella abortus biotype 1 arthritis in a horse. Aust. Vet. J., 64: 190. Cited by Tel et al. (2011).

Cyetnic, Z.; Spicic, S. and Curic, S. (2005): Isolation of B .suis biovar 3 from horses in Croatia. Vet. Rec., 156: 584-585.

Dragonas, P.N.; Stotores, E.N. and Eftathiou, LE. (1967): Bull. Soc. Vet. Hell. 18: 20 -23. After Abdel - Kadder et al. (1995).

Ehizibolo, D.O.; Gusi, A.H.; Ehizibolo, P.O.; Mbuk, E.U. and Ocholi, R.A. (2011): Serologic prevalence of brucellosis in horse stable in two North state of Nigeria. J. Equine Sci., 22 (1): 17- 19.

El-Bohy, Z.M.A. (1979): Some studies on brucellosis in donkey. M Sc. Thesis, Fac. Vet. Med., Zagazig Univ.

Esmat, M. (1996): Some studies on brucellosis in horses 7th Sci. Cong. 17-19 Nov. Fac. Vet. Med. Assiut, Egypt, pp. 637- 643.

Fahmy, I.S. and Salem, A.A. (1974): Brucella as a cause of bursitis in domestic Animals. Assiut Vet. Med. J., $1(1 \& 2)$ : $191-198$.

Garge, D.N. and Manchanda, V.P (1986): Prevalence and etiology of equine abortion. Ind. J.Anim. Sci., 56 (7): 730-735.

Göz, Y.; Babür, C.; Aydin, A. and Kilic, S. (2007): Seroprevalence of toxoplasmosis, brucellosis and listeriosis in horses in Hakkari, eastern region of Turkey, Revue. Med. Vet., 158 (11): 534-539.

Gul, S.T. and Khan, A. (2007): Epidemiology and epizoology of brucellosis: a review. Pakistan Vet. J., 27: 145-151.

Hamoda, F.K. and Montaser, A.M. (1998): Clinicoepizootiological study on brucellosis in donkeys. Beni-Suef. Vet. Med. J., 8: 105-118.

Izgur, M.; Akay, O.; Candas, A.; Inan, A.; Ayhan, $H$. and Esendal, $O$. (1988): Study on the 
prevalence of equine brucellosis in Ankara. Etlik Veteriner Mikroblyoloji - Enstitutu Dergisi, 6: 117-126.

Kazi, M.; Amin, R.; Bahman, M.B.; Rahman, M.S.; Han, J.; Park, J. and Chae, J., (2005): Prevalence of antibodies in sera of cows in Bangladesh. J. Vet. Sci. 6: 223-226.

MacMillan, A.P. and Cockrem, D.S. (1986): Observation of the long term effects of $\mathrm{B}$. abortus infection in the horse, including effects during pregnancy and lactation. Equine Vet. J., 18: 388-390.

MacMillan, A.P.; Baskerville, A.; Hambleton, P. and Corbel, M.J. (1982): Experimental Brucella abortus infection in the horse; observation during the three months following inoculation. Research in Veterinary Science 33: 351-259.

McNutt, S.H. and Murray, C. (1924): Bacterium abortum (Bang) isolated from the fetus of an aborting mare, J. Am. Vet. M.A., 65: 215.

Megid, J.; Mathias, L.A. and Robles, C.A. (2010): Clinical manifestations of brucellesis in domestc animals and humans. The Open Veterinary Science Journal, 4: 119- 126.

Musa, M.T. (2004): A serological study on Equine brucellosis in Darfur, Western sudan. The Sudan J. Vet. Res., 19: 7- 11.

Namavari, M.M.; Mohammadi, G.H.R.; Tahamtan, M.R. and Tahamtan, Y. (2008): Prevalence of brucellosis in equines of Mashhad - Iran. International Journal Of Infectious Diseases. Vol 12, page 134.

Nashed, S.M. (1977): Brucellosis in Upper Egypt (Assiut - governorate) in cattle, bufbaloes, sheep, goats and its relation to public health $\mathrm{Ph}$.
D. Thesis, Faculty of Vet. Med. Cairo University.

Ocholi, R.A.; Kawaga, J.K.P.; Ajogi, I. and Bale, J.O.O. (2004): Phenotypic characterization of Brucella strains isolated from livestock in Nigeria. Vet. Microbiology, 103: 47-53.

Omer, M.K.; Skjerve, E.; Holstad, G.; Woldehiwet, Z. and MacMillan, A.P. (2000): Prevalence of antibodies to Brucella spp in cattle, sheep, goats, horses and camels in the State of Eritrea; influence of husbandry system. Epidemiol Infect., 125: 447-453.

Sayour, A.E.M. (1995): An approach towards the use of some unconventional serological tests for the diagnosis of brucellosis. M Sc Vet. Thesis, Fact. of Vet. Med. Cairo, University.

Solmaz, H.; Tutuncu, M.; Akhan, H.A.; Aksakal, A.; Gulhan, T. and Boynukara, B. (2004): Brucellosis in horses around Van, Turkey. Indian. Vet. J., 81: 748-749.

Tahamtan, Y.; Namavari, M.M.; Mohammadi, G. and Jula, G.M. (2010): Prevalence of brucellosis in horse North - East of Iran. J. Equine Vet. Sci., 30 (7): 376-378.

Tel, O.Y.; Neva, B.A. and Oktay, K. (2011): Seroprevalence of Equine brucellosis in Southeast Turkey. YYU Veteriner Fakultesi Dergisi .22(3): 181-183.

Wadood, F.; Ahmed, M.; Khan, A.; Gul, S.T. and Rehman, N. (2009): Seroprevalence of brucellosis in horses in and around Faisalabad. Pakistan Vet. J., 29 (4): 196-198.

Yadav, M.P.; Singh, B.K. and Uppal, P.K. (1991): Sero-prevalence of brucellosis in equines in some of the states in India. Indian. J. Anim. Sci,. 62 (1): 41-42.

\footnotetext{
دراسة مصلية استبيانية علي الموقف الحالي للإجهاض المعدي(البروسيلا) في الخيول والحمير في محافظة أسيوط سعد محروس البرباوي

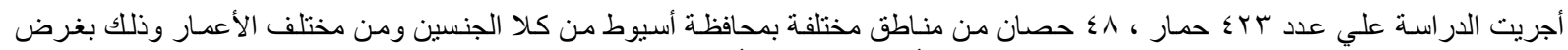

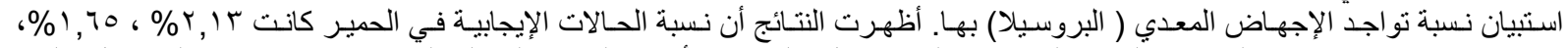

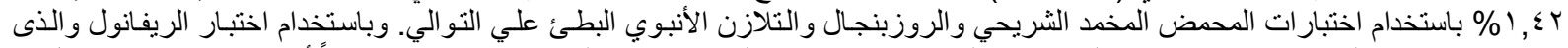

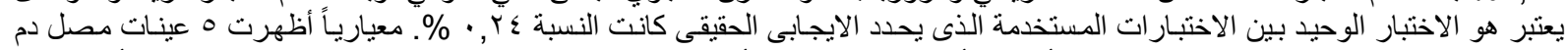

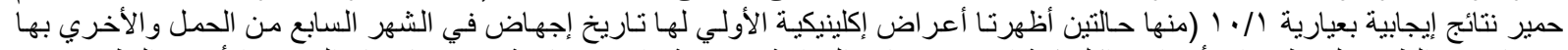

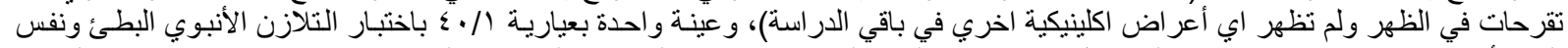

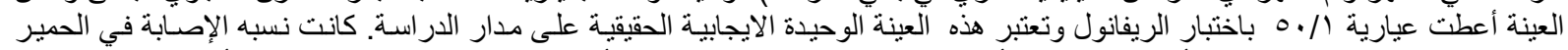

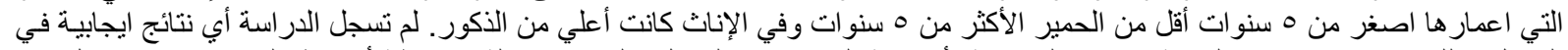

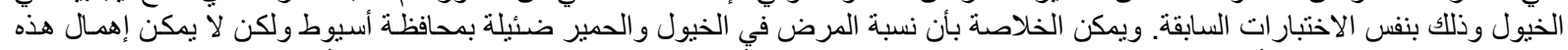

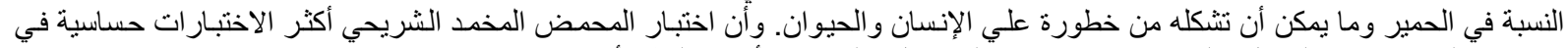

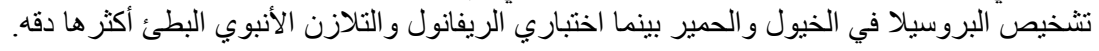

